\title{
Sensitive and selective spectrophotometric assay of doxycycline hyclate in pharmaceuticals using Folin-Ciocalteu reagent
}

\author{
PAVAGADA JAGANNATHAMURTHY RAMESH \\ KANAKAPURA BASAVAIAH* \\ NAGARAJU RAJENDRAPRASAD \\ Department of Studies in Chemistry \\ University of Mysore \\ Manasagangothri-570006, India
}

Accepted October 1, 2010
A spectrophotometric method for the determination of doxycycline (DOX) is described. The method is based on the formation of blue colored chromogen due to reduction of tungstate and/or molybdate in Folin-Ciocalteu (F-C) reagent by DOX in alkaline medium. The colored species has an absorption maximum at $770 \mathrm{~nm}$ and the system obeys Beer's law over the concentration range $0.75-12.0 \mu \mathrm{g} \mathrm{mL}^{-1} \mathrm{DOX}$. The apparent molar absorptivity is $2.78 \times 10^{4} \mathrm{~L} \mathrm{~mol}^{-1} \mathrm{~cm}^{-1}$. The limit of quantification and detection values are reported to be 0.20 and $0.08 \mu \mathrm{g}$ $\mathrm{mL}^{-1}$, respectively. Over the linear range applicable, the accuracy and precision of the method were evaluated on intra-day and inter-day basis. The reported mean accuracy value was $101.0 \pm 1.7 \%$, the relative error was $\leq 2.7$ $\%$ and the relative standard deviation was $\leq 2.5 \%$. Application of the proposed method to bulk powder and commercial pharmaceutical tablets is also presented. No significant difference was obtained between the results of the proposed method and the official BP method. The procedure described in this paper is simple, rapid, accurate and precise.

Keywords: doxycycline hyclate, Folin-Ciocalteu reagent, spectrophotometry

Doxycycline hyclate (DOX), chemically known as $(4 S, 4 \mathrm{a} R, 5 S, 5 \mathrm{a} R, 6 R, 12 \mathrm{a} S)-4$-(dimethylamino)-3,5,10,12,12a-pentahydroxy-6-methyl-1,11-dioxo-1,4,4a,5,5a,6,11,12a-octahydrotetracene-2-carboxamide hydrochloride hemiethanol hemihydrate (Fig. 1), is one of the tetracycline derivatives, which has a wide range of antibacterial activities. DOX is frequently used to treat chronic prostatitis, sinusitis, syphilis, chlamydia, pelvic inflammatory disease, acne, rosacea, and rickettsial infections.

The drug is official in British Pharmacopoeia (1), which describes the HPLC method for the determination of DOX either in raw material or in pharmaceutical formulations.

* Correspondence; e-mail: basavaiahk@yahoo.co.in 
The literature contains several methods for the determination of DOX in pharmaceutical dosage forms, including liquid chromatography (2), sequential injection chromatography (3) and capillary electrophoresis (4). A few visible spectrophotometric methods based on the different reaction schemes are found in the literature for the assay of DOX. These include FIA-spectrophotometry with copper carbonate (5) and spectrophotometry based on colour reactions with thorium(IV) (6), sodium cobaltnitrite (7) and uranyl acetate (8). Besides, kinetic spectrophotometry using $\mathrm{Cu}(\mathrm{II}) / \mathrm{H}_{2} \mathrm{O}_{2}(9)$ and multivariate calibration method (10) have also been reported by different authors.

Chromatographic techniques are the most widely used ones. Although these procedures are specific, most of the described methods are time consuming and require multistage extraction procedures. On the other hand, the reported spectrophotometric methods (5-10) are for different reasons not satisfactory for the routine quality assurance. Some of these methods suffer from disadvantages such as poor sensitivity, low stability of the species, use of organic solvent, scrupulous control of experimental variables and special equipment (Table VII).

Folin-Ciocalteu reagent (F-C) is widely used in the area of plant biology for analysis of polyphenols (11) and for the determination of many phenolic compounds in pharmaceuticals $(12,13)$ based on Folin-Ciocalteu reagent reduction. The present paper describes a reduction reaction involving F-C reagent and DOX resulting in the formation of a blue chromogen that could be measured at $770 \mathrm{~nm}$.

\section{EXPERIMENTAL}

\section{Instrument}

A Systronic model 106 digital spectrophotometer (Systronics Ltd, India) with matched 1-cm quartz cells was used for absorbance measurements.

\section{Chemicals and reagents}

Chemicals used were of analytical grade. Distilled water was used throughout the investigation.

Folin-Ciocalteu reagent (Merck, India), sodium carbonate (S.D. Fine Chem Ltd, India) were of analytical reagent grade and used without further purification. A pure DOX (pharmaceutical grade) sample was kindly provided by Lotus Pharma Ltd, India. Three brands of tablets, namely, DOX-T 100 (Dr. Reddy's Lab, India), Microdox-DT and Doxy 100 (both from Micro Labs Ltd, India) were obtained from commercial sources.

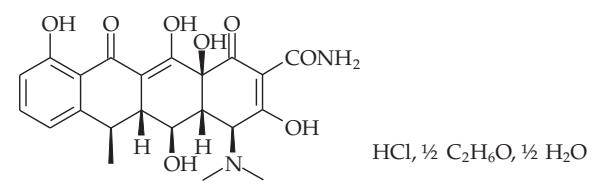

Fig. 1. Structure of doxycycline (DOX). 
P. J. Ramesh et al.: Sensitive and selective spectrophotometric assay of doxycycline hyclate in pharmaceuticals using Folin-Ciocalteu reagent, Acta Pharm. 60 (2010) 445-454.

\section{Drug and reagent solutions}

A stock solution of DOX (300 $\left.\mu \mathrm{g} \mathrm{mL}^{-1}\right)$ was prepared by dissolving pure DOX in water in a volumetric flask. Working concentration of DOX $\left(30 \mu \mathrm{g} \mathrm{mL}^{-1}\right)$ was prepared by dilution of the above stock solution with water.

The commercially available F-C reagent (defined as $2 \mathrm{eq} \mathrm{L}^{-1}$ ) was diluted with water in a ratio 1:1.

\section{Absorption spectra}

Pure DOX solution equivalent to $8.0 \mu \mathrm{g} \mathrm{mL}-1$ was mixed with $3 \mathrm{~mL}$ of $1.4 \mathrm{~mol} \mathrm{~L}^{-1}$ $\mathrm{Na}_{2} \mathrm{CO}_{3}$ and $2 \mathrm{~mL}$ of F-C reagent (1:1) in a 10-mL volumetric flask. After $20 \mathrm{~min}$, the volume was made up to the mark with water and the content was mixed throughly. A blank solution was prepared in the same way in the absence of DOX. The blank was measured against water. Maximum absorbance was obtained at $770 \mathrm{~nm}$ and was fixed as analytical wavelength.

\section{General analytical procedure}

Different aliquots of the working standard DOX solution $(30 \mu \mathrm{g} \mathrm{mL}-1)$, ranging from $0-4.0 \mathrm{~mL}$, were transferred into a series of $10-\mathrm{mL}$ volumetric flasks and the total volume was brought to $4.0 \mathrm{~mL}$ with water. To each flask, $3.0 \mathrm{~mL}$ of $1.42 \mathrm{~mol} \mathrm{~L}^{-1} \mathrm{Na}_{2} \mathrm{CO}_{3}$ and $2.0 \mathrm{~mL}$ of F-C reagent (1:1) solution were successively added by means of a microburette. The flasks were stoppered, contents were mixed and kept at room temperature for $20 \mathrm{~min}$. The volume was made up to the mark with water and the absorbance of each solution was measured at $770 \mathrm{~nm}$ against a reagent blank.

\section{Assay procedure for tablets}

An amount of finely ground tablet powder equivalent to $3.0 \mathrm{mg}$ of DOX was accurately weighed into a $100-\mathrm{mL}$ volumetric flask, the flask was shaken after addition of a $70 \mathrm{~mL}$ of water for about $20 \mathrm{~min}$ and finally the volume was made up to the mark with water. The content was kept aside for 5 min, and filtered using Whatman No. 42 filter paper. The first 10-mL portion of the filtrate was discarded and a suitable aliquot was used for the assay as described under "General analytical procedure«.

\section{Validation}

Precision and accuracy. - For 3.0, 6.0 and $9.0 \mu \mathrm{g} \mathrm{mL}-1$ of DOX, the assay described under the general analytical procedure was repeated seven times within a day to determine the repeatability (intra-day precision) and five times on different days to determine the intermediate precision (inter-day precision) of the method. Percentage relative error was evaluated between the measured mean concentration and the taken DOX concentration.

Recovery experiment was performed by applying the standard-addition technique. The recovery was assessed by determining the agreement between the measured con- 
P. J. Ramesh et al.: Sensitive and selective spectrophotometric assay of doxycycline hyclate in pharmaceuticals using Folin-Ciocalteu reagent, Acta Pharm. 60 (2010) 445-454.

centration and the added known concentration to the sample. The test was done by spiking the pre-analyzed tablet powder $\left(4.16 \mu \mathrm{g} \mathrm{mL}^{-1}\right)$ with pure DOX at three different levels $\left(2.5,5.0\right.$ and $\left.7.5 \mu \mathrm{g} \mathrm{mL}^{-1}\right)$ and the total was found by the proposed method. Each test was repeated three times.

Limits of detection (LOD) and quantification (LOQ). - The limits of detection (LOD) and quantification $(L O Q)$ were calculated according to ICH guidelines (14) using the formulae:

$L O D=3.3 \mathrm{SD} / b$ and $\mathrm{LOQ}=10 \mathrm{SD} / b$, where $\mathrm{SD}$ is the standard deviation of blank absorbance values $(n=6)$, and $b$ is the slope of the calibration line.

Selectivity. - A placebo blank of the composition: starch (10 mg), acacia (15 mg), hydroxyl cellulose $(10 \mathrm{mg})$, sodium citrate $(10 \mathrm{mg})$, talc $(20 \mathrm{mg})$, magnesium stearate (15 $\mathrm{mg})$ and sodium alginate $(10 \mathrm{mg})$ was made and its extract was prepared as described under the assay procedure for tablets and then subjected to analysis.

To assess the role of inactive ingredients on the assay of DOX, the general procedure was followed by taking 4,6 and $8 \mu \mathrm{g} \mathrm{mL}^{-1}$ DOX solution prepared using a synthetic mixture.

\section{RESULTS AND DISCUSSION}

The structural features of DOX allowed the use of F-C reagent for its assay. The proposed method is based on the formation of a blue colored chromogen when DOX reacted with the F-C reagent in the presence of sodium carbonate. Colour formation may be explained as follows based on the analogy reported by Peterson (15). Mixed acids in the F-C reagent involve the following chemical species:

$$
3 \mathrm{H}_{2} \mathrm{O} \cdot \mathrm{P}_{2} \mathrm{O}_{5} \cdot 13 \mathrm{WO}_{3} \cdot 5 \mathrm{MoO}_{3} \cdot 10 \mathrm{H}_{2} \mathrm{O} \text { and } 3 \mathrm{H}_{2} \mathrm{O} \cdot \mathrm{P}_{2} \mathrm{O}_{5} \cdot 14 \mathrm{WO}_{3} \cdot 4 \mathrm{MoO}_{3} \cdot 10 \mathrm{H}_{2} \mathrm{O}
$$

DOX probably causes a reduction of molybdate in the F-C reagent, thereby producing one or more reduced species that have a characteristic intense blue colour.

Fig. 2 shows the absorption spectra of the reaction product and reagent blank; under the same experimental conditions the blank had negligible absorbance.

\section{Method development}

Optimum conditions were fixed by varying one parameter at a time while keeping other parameters constant and observing their effect on the absorbance at $770 \mathrm{~nm}$.

To find a suitable medium for the reaction different aqueous bases were investigated. Best results were obtained with sodium carbonate. It was found that maximum and constant absorbance was obtained in the concentration range of $0.28-0.57 \mathrm{~mol} \mathrm{~L}^{-1}$ $\mathrm{Na}_{2} \mathrm{CO}_{3}$, thus $0.43 \mathrm{~mol} \mathrm{~L}^{-1}$ was fixed as optimal. 
P. J. Ramesh et al.: Sensitive and selective spectrophotometric assay of doxycycline hyclate in pharmaceuticals using Folin-Ciocalteu reagent, Acta Pharm. 60 (2010) 445-454.

Fig. 2. Absorption spectra of: a) reaction product of DOX $\left(8.0 \mu \mathrm{g} \mathrm{mL}^{-1}\right)$ with F-C reagent in $\mathrm{Na}_{2} \mathrm{CO}_{3}$ solution, b) blank.

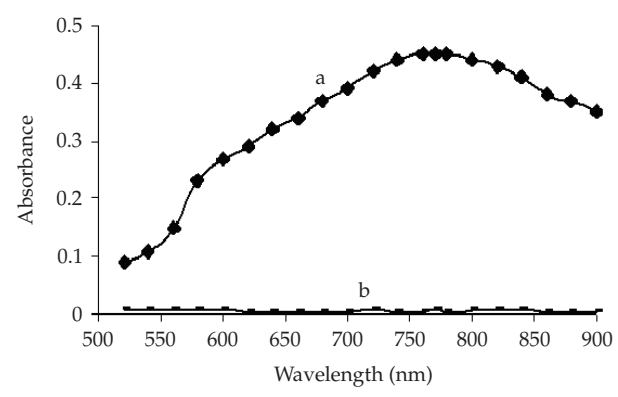

It is apparent that ten to twenty-fold diluted $\mathrm{F}-\mathrm{C}$ reagent produced maximum color intensity; F-C reagent at a dilution level of 1:20 was actually present in the reaction mixture.

The reaction time was studied by measuring the absorbance of the blue chromogen after mixing the reactants over a period from 2 min to $2 \mathrm{~h}$. Maximum colour developed in $20 \mathrm{~min}$ and was stable for at least $60 \mathrm{~min}$ thereafter. Measurements were therefore made only after 20 min throughout the investigation.

Highest sensitivity was achieved when the order of reactants addition was maintained as described in the general analytical procedure and the same was followed throughout the investigation.

\section{Validation}

A linear correlation was found between absorbance at $\lambda_{\max }$ and DOX concentration in the range $0.75-12.0 \mu \mathrm{g} \mathrm{mL}^{-1}$. Linear regression parameters within the Beer's law limits and molar absorptivity values of the method are given in Table I. Log absorbance versus log concentration plot yielded a straight line with the slope equal to 0.9922 .

Table I. Sensitivity and regression parameters

\begin{tabular}{lc}
\multicolumn{1}{c}{ Parameter } & Value \\
\hline$\lambda(\mathrm{nm})$ & 770 \\
Linear range $\left(\mu \mathrm{g} \mathrm{mL} \mathrm{m}^{-1}\right)$ & $0.75-12.0$ \\
Molar absorptivity $(\varepsilon)\left(\mathrm{L} \mathrm{mol}^{-1} \mathrm{~cm}^{-1}\right)$ & $2.78 \times 10^{4}$ \\
Limit of detection $(L O D)\left(\mu \mathrm{g} \mathrm{m}^{-1}\right)$ & 0.08 \\
Limit of quantification $(L O Q)\left(\mu \mathrm{g} \mathrm{mL}^{-1}\right)$ & 0.20 \\
Regression equation, $\mathrm{Y}=\mathrm{aX}+\mathrm{b}:$ & \\
intercept $(\mathrm{a}) \pm \mathrm{SD}_{\mathrm{a}}$ & $0.0054 \pm 0.0051$ \\
slope $(\mathrm{b}) \pm \mathrm{SD}_{\mathrm{b}}$ & $0.0531 \pm 0.0006$ \\
Regression coefficient $(R)$ & 0.9997 \\
\hline
\end{tabular}

$\mathrm{X}: \operatorname{DOX}\left(\mu \mathrm{g} \mathrm{mL} \mathrm{m}^{-1}\right)$. 
P. J. Ramesh et al.: Sensitive and selective spectrophotometric assay of doxycycline hyclate in pharmaceuticals using Folin-Ciocalteu reagent, Acta Pharm. 60 (2010) 445-454.

Table II. Evaluation of intra-day and inter-day error and precision

\begin{tabular}{ccccccc} 
& \multicolumn{3}{c}{ Intra-day $(n=7)$} & \multicolumn{3}{c}{ Inter-day $(n=5)$} \\
\cline { 2 - 7 } $\begin{array}{c}\text { DOX taken }\left(\mu \mathrm{mL}^{-1}\right) \\
3.00\end{array}$ & $\begin{array}{c}\text { DOX found } \pm \mathrm{CL} \\
\left(\mu \mathrm{g} \mathrm{mL} \mathrm{mL}^{-1}\right)\end{array}$ & $e_{\mathrm{R}}(\%)$ & RSD $(\%)$ & $\begin{array}{c}\text { DOX found } \pm \mathrm{CL} \\
\left(\mu \mathrm{g} \mathrm{mL} \mathrm{mL}^{-1}\right)\end{array}$ & $e_{\mathrm{R}}(\%)$ & RSD $(\%)$ \\
\cline { 2 - 7 } & $2.95 \pm 0.04$ & 1.7 & 1.6 & $3.08 \pm 0.08$ & 2.7 & 2.1 \\
9.00 & $6.06 \pm 0.06$ & 1.0 & 1.0 & $6.10 \pm 0.19$ & 1.7 & 2.5 \\
\hline
\end{tabular}

$\mathrm{CL}$ - confidence limits calculated from: $\mathrm{CL}= \pm t \mathrm{SD} / \sqrt{\mathrm{n}}$.

The percentage relative standard deviation values were $\leq 1.6 \%$ (intra-day) and $\leq 2.5 \%$ (inter-day), indicating high precision of the method. Percent relative error of $\leq 2.7 \%$ was evaluated. Results are summarized in Table II.

The percentage recovery values obtained were in the range from 98.9 to $103.6 \%$, with relative standard deviation $0.6-1.3 \%$. In all the cases, the results showed a fairly good accuracy of the method (Table III).

A systematic study was performed to determine the effect of the matrix by analyzing the placebo blank. In the analysis of the placebo blank solution, the absorbance in each case was equal to the absorbance of reagent blank which revealed no interference. The recovery values obtained in this study are presented in Table IV. The values of 97.4-104.3 \% with RSD values of $<3 \%$ clearly indicate non-interference of inactive ingredients in the assay.

In order to check the robustness of the method, the assay was performed using the same operational conditions but using different instruments in two different laboratories, different analysts and different elapsed times. The results obtained from inter-lab, inter-day and inter-analyst assays were reproducible. The inter-analyst RSD were within $2.5 \%$ whereas the inter-instrument and inter-lab RSDs for the same DOX concentration were less than about $2.6 \%$. The results are presented in Table V.

Table III. Recovery study by the standard addition method

\begin{tabular}{cccr}
\hline Tablet studied & $\begin{array}{c}\text { DOX in tablet extract } \\
\left(\mu \mathrm{g} \mathrm{mL}^{-1}\right)\end{array}$ & $\begin{array}{c}\text { Pure DOX added } \\
\left(\mu \mathrm{g} \mathrm{mL}^{-1}\right)\end{array}$ & $\begin{array}{c}\text { DOX recovered } \\
(\%)^{\mathrm{a}}\end{array}$ \\
\hline \multirow{2}{*}{ DOX 100 } & 4.16 & 2.50 & $98.9 \pm 1.0$ \\
& 4.16 & 5.00 & $100.1 \pm 0.9$ \\
& 4.16 & 7.50 & $102.3 \pm 1.2$ \\
DOXY 100 & 4.16 & 2.50 & $99.6 \pm 0.6$ \\
& 4.16 & 5.00 & $101.2 \pm 1.3$ \\
\hline
\end{tabular}

a Mean $\pm \mathrm{SD}, n=3$. 
P. J. Ramesh et al.: Sensitive and selective spectrophotometric assay of doxycycline hyclate in pharmaceuticals using Folin-Ciocalteu reagent, Acta Pharm. 60 (2010) 445-454.

Table IV. Selectivity study ${ }^{a}$

\begin{tabular}{cc}
\hline DOX taken $\left(\mu \mathrm{g} \mathrm{mL}^{-1}\right)$ & DOX recovered $(\%)^{\mathrm{b}}$ \\
\hline 4.00 & $98.3 \pm 1.3$ \\
6.00 & $97.4 \pm 2.2$ \\
8.00 & $104.3 \pm 2.9$ \\
\hline
\end{tabular}

a Synthetic mixture of DOX in placebo blank.

${ }^{\mathrm{b}}$ Mean $\pm \mathrm{SD}, n=3$.

\section{Analysis of pharmaceutical formulations}

The described procedure was successfully applied to the determination of DOX in pharmaceutical formulations. The results obtained were statistically compared with the official BP method (1). The official method is liquid chromatography of DOX with UV detection at $350 \mathrm{~nm}$. The results obtained by the proposed method agreed well with those of the reference method. The results were also compared statistically using Student's $t$-test for accuracy and a variance $F$-test for precision with those of the reference

Table V. Intermediate precision of the method

\begin{tabular}{cccc}
\hline \multirow{2}{*}{$\begin{array}{c}\text { DOX taken } \\
\left(\mu \mathrm{g} \mathrm{mL}^{-1}\right)\end{array}$} & $\begin{array}{c}\text { Inter-labs } \\
(n=4)\end{array}$ & $\begin{array}{c}\text { Inter-analysts } \\
(n=4)\end{array}$ & $\begin{array}{c}\text { Inter-instruments } \\
(n=4)\end{array}$ \\
\cline { 2 - 4 } & 1.6 & 2.1 & 2.5 \\
3.00 & 2.1 & 2.0 & 2.3 \\
6.00 & 2.5 & 2.5 & 2.6 \\
9.00 & & & \\
\hline
\end{tabular}

Table VI. Analysis of tablets by the proposed method and the reference method

\begin{tabular}{cccccc}
\hline \multirow{2}{*}{$\begin{array}{c}\text { Tablet brand } \\
\text { name }\end{array}$} & $\begin{array}{c}\text { DOX taken } \\
\left(\mu \mathrm{g} \mathrm{mL}^{-1}\right)\end{array}$ & $\begin{array}{c}\text { Found } \pm \text { SD } \\
\text { Reference } \\
\text { method }^{\mathrm{a}}\end{array}$ & $\begin{array}{c}\text { Proposed } \\
\text { method }^{\mathrm{a}}\end{array}$ & $\begin{array}{c}\text { Student's } \\
t \text {-value }\end{array}$ & $\begin{array}{c}\text { Variance ratio } \\
F \text {-value }\end{array}$ \\
\cline { 3 - 5 } DOX-T 100 & 6.00 & $5.99 \pm 0.03$ & $5.97 \pm 0.03$ & 1.05 & 1.00 \\
DOXY 100 & 9.00 & $8.94 \pm 0.07$ & $9.01 \pm 0.04$ & 2.01 & 3.06 \\
Microdox-DT & 6.00 & $5.97 \pm 0.03$ & $5.96 \pm 0.03$ & 0.53 & 1.00 \\
100 & 9.00 & $8.96 \pm 0.05$ & $9.05 \pm 0.06$ & 2.59 & 1.44 \\
\hline
\end{tabular}

a Mean $\pm \mathrm{SD}, n=5$.

Tabulated $t$-value at the $95 \%$ confidence level is 2.77; tabulated F-value at the $95 \%$ confidence level is 6.39 . 
P. J. Ramesh et al.: Sensitive and selective spectrophotometric assay of doxycycline hyclate in pharmaceuticals using Folin-Ciocalteu reagent, Acta Pharm. 60 (2010) 445-454.

Table VII. Comparison of performance characteristics of the proposed method with the published method

\begin{tabular}{|c|c|c|c|c|c|c|}
\hline Reagent/s used & Methodology & $\begin{array}{l}\lambda_{\max } \\
(\mathrm{nm})\end{array}$ & $\begin{array}{l}\text { Linear } \\
\text { range }\end{array}$ & $\begin{array}{l}L O Q / L O D \\
\left(\mu \mathrm{g} \mathrm{mL}^{-1}\right)\end{array}$ & Remarks & Ref. \\
\hline $\begin{array}{l}\text { Copper } \\
\text { carbonate }\end{array}$ & $\begin{array}{l}\text { Complex colour } \\
\text { measured }\end{array}$ & 395 & $\begin{array}{l}10.0-80.0 \\
\mathrm{mg} \mathrm{mL}^{-1}\end{array}$ & NA & $\begin{array}{l}\text { FIA assembly, } \\
\text { less sensitive }\end{array}$ & 17 \\
\hline $\operatorname{Th}(\mathrm{IV})$ & $\begin{array}{l}\text { Yellow complex } \\
\text { measured }\end{array}$ & 398 & $\begin{array}{l}0.04-3.2 \\
\mu \mathrm{g} \mathrm{mL}-1\end{array}$ & NA & $\mathrm{pH}$ dependent & 18 \\
\hline $\begin{array}{l}\text { Sodium } \\
\text { cobaltnitrite } \\
\text { and acetic acid }\end{array}$ & $\begin{array}{l}\text { Product be- } \\
\text { tween DOX and } \\
\text { reagent in ace- } \\
\text { tic acid mea- } \\
\text { sured }\end{array}$ & 243 & $\begin{array}{l}0.01-0.03 \\
\mathrm{mg} \mathrm{mL}^{-1}\end{array}$ & NA & $\begin{array}{l}\text { heating, less } \\
\text { sensitive }\end{array}$ & 19 \\
\hline $\begin{array}{l}\text { Uranyl } \\
\text { acetate-DMF } \\
\text { medium }\end{array}$ & $\begin{array}{l}\text { 1:1 complex } \\
\text { between DOX } \\
\text { and uranyl } \\
\text { acetate in DMF } \\
\text { measured }\end{array}$ & 405 & $\begin{array}{c}0-135 \\
\mu \mathrm{g} \mathrm{mL} \mathrm{mL}^{-1}\end{array}$ & NA & $\begin{array}{l}\text { organic solvent, } \\
\text { less sensitive }\end{array}$ & 20 \\
\hline $\mathrm{Cu}(\mathrm{II}) / \mathrm{H}_{2} \mathrm{O}_{2}$ & $\begin{array}{l}\text { Decrease in } \\
\text { absorbance } \\
\text { measured } \\
\text { kinetically }\end{array}$ & 510 & $\begin{array}{c}2.97-17.78 \\
\mu \mathrm{g} \mathrm{mL}-1\end{array}$ & $1.89 / 0.57$ & $\begin{array}{l}\text { buffers, control } \\
\text { of experimental } \\
\text { variables, special } \\
\text { equipment }\end{array}$ & 21 \\
\hline $\begin{array}{l}\text { DMF/ } \\
\text { NaOAc-AcOH } \\
\text { buffer (pH 4.5) }\end{array}$ & $\begin{array}{l}\text { Partial } \\
\text { least-squares } \\
\text { multivariate } \\
\text { method applied } \\
\text { for a ternary } \\
\text { mixture }\end{array}$ & $277-349$ & $\begin{array}{c}1.7-42 \\
\mu \mathrm{g} \mathrm{mL} \mathrm{mL}^{-1}\end{array}$ & NA & $\begin{array}{l}\text { organic solvent, } \\
\text { pH dependent }\end{array}$ & 22 \\
\hline $\begin{array}{l}\text { F-C reagent/ } \\
\mathrm{Na}_{2} \mathrm{CO}_{3}\end{array}$ & $\begin{array}{l}\text { Blue colored } \\
\text { chromogen was } \\
\text { measured }\end{array}$ & 770 & $\begin{array}{c}0.75-12 \\
\mu \mathrm{g} \mathrm{mL} \mathrm{m}^{-1}\end{array}$ & $0.20 / 0.08$ & $\begin{array}{l}\text { no heating } \\
\text { or extraction, } \\
\text { more sensitive }\end{array}$ & $\begin{array}{c}\text { Present } \\
\text { work }\end{array}$ \\
\hline
\end{tabular}

NA - not available

method at $95 \%$ confidence level. The results showed that the calculated $t$-and $F$-values did not exceed the tabulated values, inferring that the proposed method is as accurate and as precise as the reference method. The results are shown in Table VI. The favourable accuracy and RSD values of the new method harmonize well with the previous validation data.

The proposed method was found to be superior to the reported methods with respect to speed, simplicity, sensitivity and cost-effectiveness. It is less costly and it does not require expensive equipment, high-cost reagents or specialized technicians. In addition, it is free from extreme experimental or stringent conditions like heating at high temperature or extraction procedure (for comparasion see Table VII). 
P. J. Ramesh et al.: Sensitive and selective spectrophotometric assay of doxycycline hyclate in pharmaceuticals using Folin-Ciocalteu reagent, Acta Pharm. 60 (2010) 445-454.

\section{CONCLUSIONS}

A new sensitive spectrophotometric method has been developed, optimized and validated for the determination of doxycycline in bulk drug and in tablets. The simplicity, sensitivity and selectivity make the method a suitable alternative to the HPLC methods. Other characteristics such as short performance time, ease of handling and non-usage of organic solvents, also suggest this procedure as a routine laboratory method. Therefore, the proposed method can be adopted for the assay of DOX in quality control laboratories where modern instruments are not available.

Acknowledgement. - The authors thank Lotus Pharama Ltd, Bangalore, India, for donating pure DOX. Two of the authors (PJR and NRP) thank the authorities of the University of Mysore, Mysore, for permission and facilities. One of the authors (PJR) is indebted to the Jubilant Organosys Ltd, Mysore, India, for their kind permission to pursue his Ph.D. degree programme. NRP is also grateful to the University Grants Commission, New Delhi, India, for awarding a Meritorious Research Fellowship.

\section{REFERENCES}

1. British Pharmacopoeia, Vol. II, Her Majesty's Stationery Office, London 1999, p. 1805.

2. S. S. Mitic, G. Z. Miletic, D. A. Kostc, D. C. Naskovic-Djokic, B. B. Arsic and I. D. Rasic, A rapid and reliable determination of doxycycline hyclate by HPLC with UV detection in pharmaceutical samples, J. Serb. Chem. Soc. 73 (2008) 665-671; DOI: 10.2298/JSC0806665M.

3. D. Satinsky, L. M. L. Dos Santos, H. Sklenářová, P. Solich, M. C. B. S. M. Montenegro, A. N. Araújo, Sequential injection chromatographic determination of ambroxol hydrochloride and doxycycline in pharmaceutical preparations, Talanta 68 (2005) 214-218; DOI: 10.1016/j.talanta. 2005.06.059.

4. A. Van Schepdael, R. Kibaya, E. Roets and J. Hoogmartens, Analysis of doxycycline by capillary electrophoresis, Chromatographia 41 (1995) 367-369; DOI: 10.1007/BF02688053.

5. J. L. Lopez Paz and J. M. Calatayud, Copper carbonate as a solid-bed reactor for spectrophotometric determination of doxycycline and oxytetracycline in an unsegmented continuous flow assembly, J. Pharm. Biomed. Anal. 11 (1993) 1093-1098; DOI: 10.1016/0731-7085(93)80087-H.

6. Y. S. Chandra, V. S. Rao, P. S. R. Murthy, Y. Siva Chandra and V. Suryanarayana Rao, Determination of hostacycline and doxycycline using thorium(IV) as spectrophotometric reagent, Indian J. Pharm. Sci. 58 (1996) 157-159.

7. M. S. Mahrous and M. M. Abdel-Khalek, Spectrophotometric determination of phenothiazines, tetracyclines and chloramphenicol with sodium cobaltinitrite, Talanta 31 (1984) 289-291; DOI: 10.1016/0039-9140(84)80281-7.

8. U. Saha, A. K. Sen, T. K. Das and S. K. Bhowal, Spectrophotometric determination of tetracyclines in pharmaceutical preparations, with uranyl acetate, Talanta 37 (1990) 1193-1196; DOI: 10.1016/0039-9140(90)80192-I.

9. S. M. Sunaric, S. S. Mitic, G. Z. Miletic, A. N. Pavlovic and D. Naskovic-Djokic, Determination of doxycycline in pharmaceuticals based on its degradation by $\mathrm{Cu}(\mathrm{II}) / \mathrm{H}_{2} \mathrm{O}_{2}$ reagent in aqueous solution, J. Anal Chem. 64 (2009) 231-237; DOI: 10.1134/S1061934809030046.

10. A. F. Espinosa-Mansilla, F. Salinas and I. De Orbe Paya, Simultaneous determination of sulfadiazine, doxycycline, furaltadone and trimethoprim by partial least squares multivariate calibration, Anal. Chim. Acta. 313 (1995) 103-112; DOI: 10.1016/0003-2670(95)00252-U. 
P. J. Ramesh et al.: Sensitive and selective spectrophotometric assay of doxycycline hyclate in pharmaceuticals using Folin-Ciocalteu reagent, Acta Pharm. 60 (2010) 445-454.

11. N. Cicco, M. T. Lanorte, M. Paraggio, M. Viggiano and V. Lattanzio, A reproducible, rapid and inexpensive Folin-Ciocalteu micro-method in determining phenolics of plant methanol extracts, Microchem. J. 91 (2009) 107-110; DOI: 10.1016/j.microc.2008.08.01.

12. N. P. Sadler and H. Jacobs, Application of the Folin-Ciocalteu reagent to the determination of salbutamol in pharmaceutical preparations, Talanta 42 (1995) 1385-1388; DOI: 10.1016/0039-9140(95)01534-I.

13. C. S. P. Sastry and J. S. V. M. Lingeswara-Rao, Spectrophotometric methods for the determination of methotrexate in pharmaceutical formulations, Anal. Lett. 29 (1996) 1763-1768; DOI: 10.1080/ 00032719608001522.

14. International Conference on Harmonisation of Technical Requirements for Registration of Pharmaceuticals for Human Use, ICH Harmonised Tripartite Guideline, Validation of Analytical Procedures: Text and Methodology Q2(R1), Complementary Guideline on Methodology dated 06 November 1996, incorporated in November 2005, London; http:/ / www.ich.org/LOB/media/MEDIA417.pdf.

15. G. L. Peterson, Review of the Folin phenol protein quantitation method of Lowry, Rosebrough, Farr and Randall, Anal. Biochem. 100 (1979) 201-220.

\section{$S A \check{Z} E T A K$}

\section{Osjetljivo i selektivno spektrofotometrijsko određivanje doksiciklin hiklata u farmaceutskim pripravcima koristeći Folin-Ciocalteuov reagens}

PAVAGADA JAGANNATHAMURTHY RAMESH, KANAKAPURA BASAVAIAH i NAGARAJU RAJENDRAPRASAD

U radu je opisana spektrofotometrijska metoda određivanja doksiciklina (DOX). DOX u bazičnom mediju reducira volframat i/ili molibdat u Folin-Ciocalteuovom (F-C) reagensu pri čemu nastaje modro obojeni kromogen. Obojeni produkt ima apsorpcijski maksimum pri $770 \mathrm{~nm}$. Sustav podliježe Beerovom zakonu u koncentracijskom području $0,75-12,0 \mu \mathrm{g} \mathrm{mL}^{-1}$ DOX. Molarni apsorpcijski koeficijent iznosi 2,78 $\times 10^{4} \mathrm{~L} \mathrm{~mol}^{-1}$ $\mathrm{cm}^{-1}$. Granice kvantifikacije i detekcije su 0,20 , odnosno $0,08 \mu \mathrm{g} \mathrm{mL}{ }^{-1}$. Unutar linearnog područja procijenjene su ispravnost i preciznost unutar jedne i više eksperimentalnih serija. Ispravnost je iznosila $101,0 \pm 1,7 \%$, relativna pogreška $\leq 2,7 \%$, a relativna standardna devijacija $\leq 2,5 \%$. Ispitana je i primjenjivost predložene metode na praškasti uzorak doksiciklina i komercijalne tablete. Usporedbom rezultata dobivenih predloženom metodom i oficijelnom BP metodom nisu ustanovljene značajne razlike. Opisana metoda je jednostavna, brza, ispravna i precizna.

Ključne riječi: doksiciklin hiklat, Folin-Ciocalteuov reagens, spektrofotometrija

Department of Studies in Chemistry, University of Mysore, Manasagangothri, India-570006 